\title{
THE BENEFIT OF APPLICATION OF "STR TECHNOLOGY" IN IDENTIFYING THE CHARRED BODY OF A PREGNANT MOTHER AND HER FETUS
}

\author{
Adel M. A. Elberry ${ }^{A}$, Amany A. Abdulhakim Moussa ${ }^{B}$, Mohammed A. Al-Ramadi \\ C, \\ , Fadwa A. Elroby ${ }^{D}$ \\ A. Forensic department, General administration of criminal evidences, public security, \\ KSA \\ B. Faculty of Biotechnology, October University for modern sciences and arts \\ C. Egyptian Forensic Medicolegal Authority. \\ D. Forensic Medicine and Clinical Toxicology Department, Faculty of medicine, Beni- \\ Suef University
}

Corresponding author:

Fadwa A Elroby

Dr_fido_311@yahoo.com

00201007824092

ABSTRACT

Background: Identification of totally or partially burnt human remains and putrefied bodies is considered a serious forensic issue. In buried bodies, humus from soil can interfere with the DNA extraction process or may inhibit downstream amplification of the extracted DNA. In the present study, a partially charred body was found lying on its back with missing of both upper and lower limbs except the left humerus and half of the left tibia and fibula. In this cases, conventional fingerprint is impossible as the foot and hands became totally burnet. Therefore DNA usage is the main clue of this casa for perfect identification of the victim or highly putrefied bodies by "autosomal STR analysis" which became a method of choice for the identification of human remains", Method: Using of STR technology help in identification of the dead fetus and solve this case and identification of the suspect and prove that he is the father

Result: The present case report describes the application of DNA technology in identifying totally fired body, samples were taken from the victim and suspect, the result was the body of a pregnant woman who was put on fire after being killed by her boyfriend.

KEYWORDS DNA, STR, locus, fire, burn, identification

\section{CASE PRESENTATION}

Identification is considered an important objective in Forensic Medicine whether in cases of mass disaster or individual crises (Ali et al., 2016)
The story begins on one winter night by discovering a burnt human body by the residents in the backyard of three multi-storied residential blocks in the district of El Sharabia (Cairo city, Egypt). Upon arrival at the scene, a partially charred body was found lying on its back with missing of both upper and lower limbs except for the 
left humerus and half of the left tibia and fibula (figure 1). The body was surrounded by the ashes of burnt papers. The gender and the identity of the corpse could not be established at the scene because of the partial charring of the entire musculature. After conducting some basic crime scene investigations and interrogations from the residents, the body was released by the police to be transferred to the morgue for autopsy and other postmortem investigations.

In the morgue, the corpse was identified as a partially charred body with missing upper and lower limbs except the left humerus and half of the left tibia and fibula possibly because of $6^{\text {th }}$-degree burns (fig. 1)

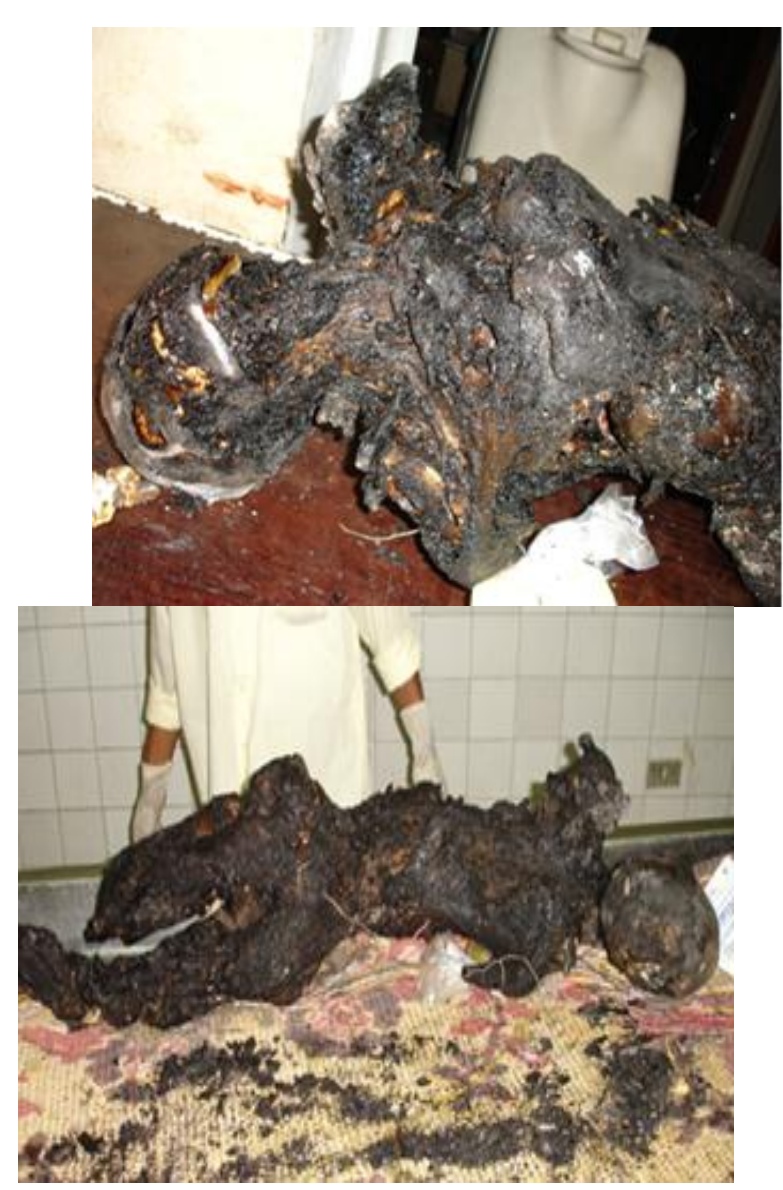

Figure 1: The burnt body( corpse).
The body was presented with a pugilistic attitude due to the shrinkage of muscles and tendons. Upon opening the body, the internal organs were found to be reduced in size. Three plain AP X-rays were taken to identify the gender and any other underlying cause of death. Anatomy of the skull and pelvis revealed that the body was of a burnt female in her late thirties. Autopsy further revealed the presence of a dislocation of the right arm of thyroid cartilage and also in the left arm of hyoid bone [Fig. 4]as well as the present of uterus with erythema on its outer surface which appeared between the burnt molten mucosa and there is a dead fetus within about of 3.4 $\mathrm{cm}$ in length (the third uterine months) [fig. 2 and 3].

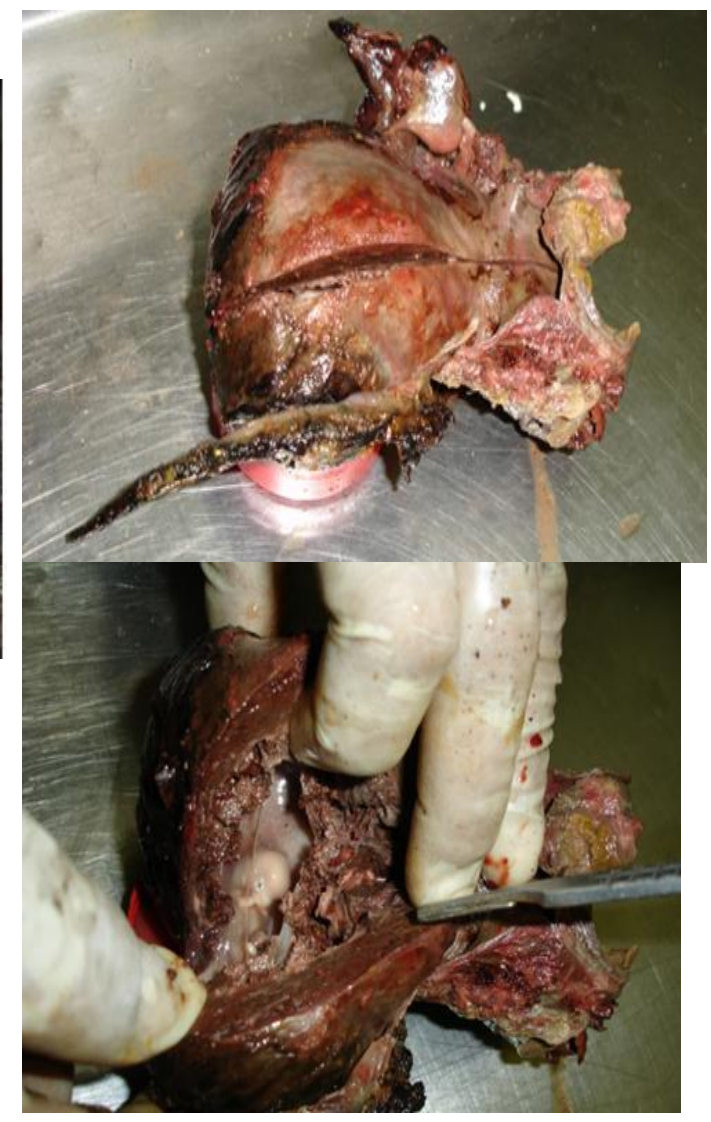

Figure 2 :The uterus with dead fetus inside it. 


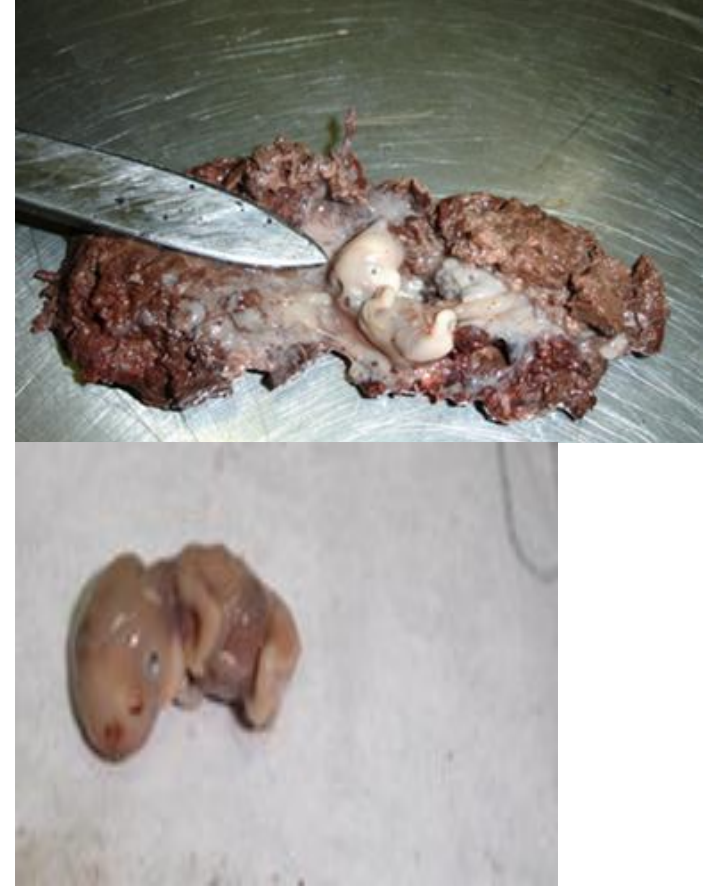

Figure 3 : The dead fetus.

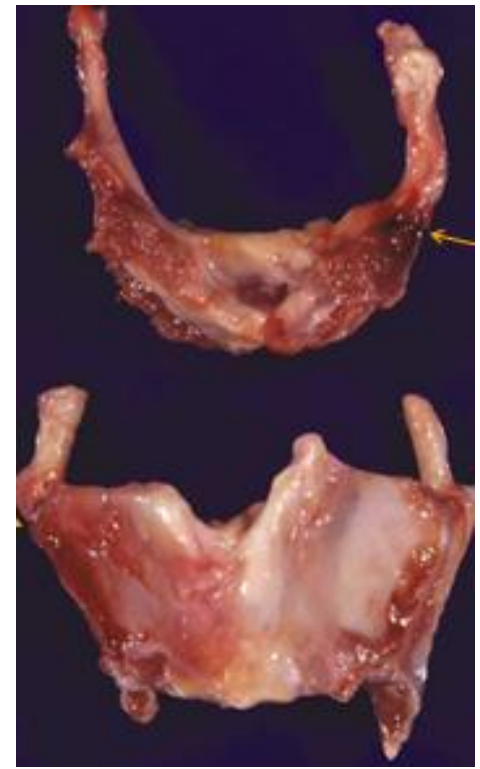

Figure 4 : Dislocation of the left big arm of hyoid bone, and of the right big arm of the tracheal cartilage.

Samples of tissue from uterus, and the fetus as well as part of the burnt bone which in a good condition for DNA analysis. A part of the burnt tissue sent to the chemical laboratory to find out the cause of the fire. The policeman sent the suspect to the medical lab to take blood sample to compareit with the fetus sample and the burnt body to see whether the fetus of the victim is his own son or not.

\section{MATERIALS AND MRTHODS Bone preparation}

All bones were cleared mechanically, dried, washed, put in $\mathrm{NaOCl} 10 \%$ for a few minutes and washed again, milled (6×90s cycles) in liquid nitrogen using a cryogenic mill (6850 Freezer Mill SpexCertiPrep, USA).

We prepare each bone separately by using disposable sterile toolset, the room was designed specially for this procedure.

\section{Extraction of DNA}

The Bone powder was left overnight to be digested, phenolchloroform-isoamyl alcohol was used to extract DNA, then purified and concentrated on micro-column "UltracelYM 100, Microcon" to $15 \mu 1$, incubation of $500 \mathrm{mg}$ of bone powder with $2.5 \% \mathrm{NaOCl}$ for 4 hours. Washing The pellet with water and ethanol $95 \%$ and suspended again in absolute ethanol, put in a centrifuge and left to dry over the night. The dried material was sonicated in ethanol $95 \%$, put in a vortex and settled. Then washing the precipitant with $2.5 \%$ $\mathrm{NaOCl}$ and water and decalcified in $0.5 \mathrm{M}$ EDTA $\mathrm{pH}$ 8.0, with a few exchanges of EDTA solution then centrifuged. The powder of the bone that was calcified incubated Bone powder that was calcified was incubated with proteinase $\mathrm{K}$, DTT, EDTA, $\mathrm{NaCl}$ and SDS for thirty min at temperature $60^{\circ} \mathrm{C}$ and then left the whole night at temperature $37^{\circ} \mathrm{C}$. The extraction of DNA was done by purification of phenol- chloroformisoamyl alcohol, and concentrated by ultrafiltration (Ultracel YM 100, Microcon) to $15 \mu \boldsymbol{\mu l}$ Total demineralization technique (TD) was used in extraction of DNA. Incubation 
of $500 \mathrm{mg}$ of bone powder all the night at $56^{\circ} \mathrm{C}$ In the buffer "0.5 M EDTA, $1 \%$ lauryl sarcosyl) and 20 ul of 20 $\mathrm{mg} / \mathrm{ml}$ proteinase $\mathrm{K}$, and concentrated and purified by using (Centricon Plus20, Centricon 30 centrifugal filter unit (Millipore)". Appropriate control and decontamination processes were followed during all steps of extraction.

\section{DNA quality:}

Evaluation of the degree of Regaining of DNA and Extraction of DNA using PCR (polymerase chain reaction) inhibitors by Real-Time PCR with "QuantifierHuman kit (Applied Biosystems, USA).

\section{STR genotyping:}

Amplification was done by using "Identifiler1 Plus, AmpF ' STR1 NGMTM (Applied Biosystems, USA)". 9700 GeneAmp cycler was used for Cycling, the following design was performed (Initial denaturation for 10 minutes at temperature $95^{\circ} \mathrm{C}$ followed by 28 cycles 1 minute at temperature $94^{\circ} \mathrm{C}$, for 1 minute at temperature $72^{\circ} \mathrm{C}$ then finally the last extension for 45 minutes at temperature $60^{\circ} \mathrm{C}$. The reactions began with volumes 25 with DNA 10 then we get final concentration (from $0.5 \mathrm{ng}$ to1ng), capillary electrophoresis was performed using "Applied Biosystems 3130xl geneticanalyseris" and profiling analysis was done using "GeneMapper ID v3.2.1.".

\section{RESULTS}

The cause of burnt body death is asphyxia. The cause of death of the fetus is due to the stop of bloodfeeding as a result of death of his mother by asphyxia (throttling pressure on the neck of the mother). The causal material of burning is Kerosene. The fetus is the son of both the burnt female and the suspect. (Table NO: 1)
Table 1: The Identifier STR profiles of corpse (burnt body), suspect, and the fetus.

\begin{tabular}{|c|c|c|c|}
\hline $\begin{array}{c}\text { STR } \\
\text { Loci }\end{array}$ & $\begin{array}{c}\text { Burnt } \\
\text { body }\end{array}$ & Suspect & Fetus \\
\hline D3S1358 & 15,16 & 15,17 & 15,16 \\
\hline CSF1PO & 10,11 & 10,13 & 10,13 \\
\hline D7S820 & 8,10 & 11,13 & 10,11 \\
\hline D21S11 & 27,24 & 28,30 & 24,28 \\
\hline D8S1179 & 13,14 & 14,15 & 13,15 \\
\hline D19S433 & 12,14 & $15,15.2$ & $12,15.2$ \\
\hline D2S1338 & 17,17 & 18,18 & 17,18 \\
\hline D16S539 & 9,11 & 11,12 & 11,12 \\
\hline D13S317 & 10,13 & 11,12 & 10,12 \\
\hline THO1 & 6,10 & 7,8 & 6,8 \\
\hline FGA & 22,28 & 21,26 & 22,26 \\
\hline D5S818 & 10,14 & 12,13 & 12,14 \\
\hline D18S51 & 13,13 & 15,17 & 13,15 \\
\hline TPOX & 8,12 & 8,11 & 8,8 \\
\hline VWA & 14,19 & 16,18 & 14,16 \\
\hline
\end{tabular}

Using of STR technology help in the identification of the dead fetus and solve this case and identification of the suspect and prove that he is the father

\section{DISCUSSION}

In this study there is shrinking, loss of both upper and lower limbs with the fixation of tissues in whole body that agree with (Tosoko, 2004) that stated that the burnet body shows broad spectrum morphological finding 
for example range from minor, local, superficial burns of the skin to calcined skeletal remains without any soft tissue left and total incineration.

In our study, there is successful DNA amplification with the AmpF'STR1 Identifiler1 Plus AmpF'STR1 NGMTM PCR Amplification Kit which agree with the study of (Tucker et al., 2011)that stated that "the usage of AmpF'STR1 NGM TM with the ESS loci is tolerant more commonly with the inhibitors so that we can face the obstacles in case of processing the skeletal remains that are compromised. unlike the study (Edson et al., 2005) that stated that the burned remains became brittle, blackened and friable so failure rate of typing DNA is expected.

Genetic profiles can be determined according to the examination of samples collected from unknown deceased of unknown identity which is a routine test must be done in forensic laboratory, time place and surrounding circumstanced determine which biological sample is suitable for DNA extraction, in some case the bone, teeth , and nails of the deceased bodies is the only source for DNA extraction such as complete skeletonization, charred bodies a major decay of the crops as hard tissue are resistant to autolysis, many factors affect the degree of postmortem decomposition and in the same time affect DNA extraction. Factors such as humidity, high or low temperature, light water or dry air affect DNA extraction(Dragana et al., 2015).

In our study, we took a sample for the DNA analysis from the tissue of the uterus, and 2 burnt ribs which were in a good condition. Like the study of (Kapiska and Szczerkowska,2004) that stated that the process of genetic identification depends on these types of specimens that containing a large amount of degraded DNA that usually depends on the analysis of microsatellite loci - STRs. DNA isolation by silica and a commercial kit (Promega) gave a full STR genotype only in the case of the burned body (Kapiska and Szczerkowska, 2004). In present casework, using AmpF'STR1 Identifiler1 Plus was the right decision for getting complete DNA profiles from the burned bones.

Schwark et Al, achieved better results from DNA amplification of burnt bones obtained from actual cases (used autosomal STRs 1identifiler kit) (Schwark et al., 2011), Shahzadet et al., find a complete DNA profiles for the identification of 32 completely burnt persons including 3 families from their remains in a vehicle by Amp Fl STR Identifiler Plus® ${ }^{\circledR}$ Kit and Amp Fl STR Y-filer ${ }^{\circledR} \mathrm{Kit}^{9}$.

\section{CONCLUSION}

Extraction of DNA is an essential step when we want to recover a highly degraded and highly damaged DNA obtained from skeletal remains, and for DNA profiling used for the identification process of a missed person. Our study, shows that simple DNA extraction technique modifications will highly improve the success rate of DNA typing, and provide conclusive, reliable profiles using different amplification kits even when working with difficult samples. Our results show that the "AmpF'STR1 NGMTM Amplification Kit" is highly accurate in genotyping the samples with degraded DNA samples by using STR loci and increase sensitivity and tolerability of common to improve the profiling from a very low quantity material of DNA. 


\section{REFERENCE}

Albinsson L., Noren L., Hedell R., (2011), Swedish population data and concordance for the kits PowerPlex1 ESX 16 System, PowerPlex1 ESI 16 System AmpFISTR1 NGMTM, AmpFISTR1 SGMTM Plus and Investigator ESSplex, Forensic Sci. Int. Genet. 5 e89-92.

Ali M. I., Abdel-Karim R. I. , Mahmoud R. M. and Hagres A. H. , (2016),EFFECT OF DIFFERENT HUMAN MUSCLE TISSUE PRESERVATIVES ON QUALITY AND QUANTITY OF DNA: MEDICO LEGAL ASPECT, Egypt J. Forensic Sci. Appli. Toxicol; Vol 16 (1): 179191.

Anđelinović S, Sutilović D, ErcegIvkošić I, Škaro V, Ivkošić A, Paić F, et al., (2005), Twelveyear experience in identification of skeletal remains from mass graves. Croat Med J.; 46:530-9.

Dragana Z., Stojan P. ,Miljen Maletina, Radenko V., Dragan D., (2015). Case report: DNA identification of burned skeletal remains, Forensic Science International: Genetics Supplement; Series 5; e444-e446.

Edson H.A., et al., , (2005), Success rates for recovering mitochondrial DNA (mtDNA) from 4000 "ancient" human skeletal remains, Proceedings of The 17th Meeting of the International Association of Forensic Sciences,; Hong Kong, A0606. In: Philip SL Beh (Ed.) Hong Kong: International Association of Forensic Sciences/Hong Kong Forensic Science Society, pp. 58.

Kapiska E., Szczerkowska Z., (2004), Personal identification on nuclear DNA extraction from bone of deceased individual, Problems of
Forensic Sciences, vol. LX, 104116.

Jakubowska J, Maciejewska A, Pawlowski R, (2012) , Comparison of three methods of DNA extraction from human bones with different degrees of degradation. Int J Legal Med; 126: 173-178.

Marjanović D, Durmić-Pašic A, Kovačević L, Avdić J, Džehverovic M, Haverić S, et al., . (2009) .DNA Identification of skeletal remains of communist armed forces victims during and after World War II: combined Ychromosome short tandem repeat (STR) and miniSTR approach. Croat Med J. ; 50:296304.

Schwark T, Heinrich A, PreußePrange A, Wurmb-Schwark NV. (2011), Reliable genetic identification of burnt human remains. Forensic SciInt Genet.; 5:393-399.

Shahzad M, Shafique M, Hussain M, Shan MA, Perveen R, Ziaurehman, Idrees M,. (2016), Successful DNA Profiling for Identification of burnt Families from their bones using AmpF $\ell$ STR Identifiler ${ }^{\circledR}$ Plus Kit. Adv. Life Sci. j.; 3(2); 59-62.

Tsokos M, (2004), Institute of Legal Medicine University of Hamburg Germany, Forensic Pathology Review.

Tucker A.J., Hopwood C.J. et al.,(2011), Developmental validation of the PowerPlex1ESI 16 and PowerPlex1 ESI 17 Systems: STR multiplex for the new European standard, Forensic Sci. Int. Genet. 5 ; 436-448. 


$$
\text { الملخص العربى }
$$

Adel M. A. Elberry ${ }^{A}$, Amany A. Abdulhakim Moussa ${ }^{B}$, Mohammed A. Al-Ramadi C,

$$
\text { , Fadwa A. Elroby }{ }^{\mathrm{D}}
$$

A. Forensic department, General administration of criminal evidences, public security,

$$
\text { KSA }
$$

B. Faculty of Biotechnology, October University for modern sciences and arts C. Egyptian Forensic Medicolegal Authority.

D. Forensic Medicine and Clinical Toxicology Department, Faculty of medicine, BeniSuef University

$$
\begin{aligned}
& \text { عادل البرى' ، امانى عبد الحكيم موسى؟، محمد الرمادى"، فدوى الروبى؛ } \\
& \text { اققم الطب الشرعى ،الهيئة العامة للادلة الجنائية،الامن العام، المملكة العربية السعودية } \\
& \text { r بكلية العلوم البيولوجية التكنولوجية، جامعة اكتوبر للعلوم العديثة والفنون } \\
& \text { r-مصلحة الطب الثرعى ، جمهورية مصر العربية } \\
& \text { ـ ـقسم الطب الثرعى و السموم ، كلية الطب، جامعة بنى سويف }
\end{aligned}
$$

يعد الاستعراف على الجثث المتفحمة كليا او جزئيا او الاستعراف على الجثث المتعفنه رميا من احد اهم المشاكل فى علم الطب الثرعى، فى حالات الجثث المدفونة تعوق الاتربة و الثوائب الموجودة فى التربة عملية استخراج الحامض النووى DNA وفى بيعض الاحيان تعوق عملية تضاعف الحمض المستخرج،فى هذه القضية .. وجدث جثة متفحمة جزئيا ترقد على ظهرها والاطراف السفلية والعلوية مفقودة ما عدا بعض اجزاء الجهة اليسرى ،، فى هذه القضية يعد الاستعراف عن طريق باستخدام بصمات الاصابع مهمة مستحيلة نظرا لفقدان الاصابع ،،يعتبر الاستعؤاف عن طريق الحامض النووى (DNA) هى الطريقة الامثل فى هذه القضية، تم اخذ عينات من الام والطقل والمشتبه به وتم حل القضية. 